\title{
Power Play in the German Wine Business: Are German Wine Co-operatives able to Use their Power to manage their Business Relationships?
}

\author{
*Jon Henrich Hanf ${ }^{1}$, Vera Belaya ${ }^{2}$, Erik Schweickert ${ }^{1}$ \\ ${ }^{1}$ University of Applied Sciences, Campus Geisenheim, Germany \\ ${ }^{2}$ Leibniz Institute of Agricultural Development in Central and Eastern Europe (IAM0), Germany \\ *jon.hanf@hs-rm.de
}

\begin{abstract}
Due to the pyramidal-hierarchical structure of supply chain networks power is an essential part of them and the fact that it is very often unequally distributed among the participants is quite obvious, which might represent great difficulties for member-owned enterprise coops. By clarifying the concept of power and identifying its five different sources, we were able to build hypotheses of how power affects cooperation and coordination - the two main elements of chain management in wine business. The first aim of our research is to elaborate on the question of power. Furthermore, we will construct some hypotheses regarding the use of power as a chain management instrument. Our second aim is to apply our general findings to the wine production chain, analysing the power play between cooperatives and retailers, and between cooperatives and their members. Due to the explorative nature of our study, we based the elaboration of our second aim on oral interviews, which were conducted in 2009, as well as in 2010, at five major international food and beverage fairs (twice ProWein, Anuga, and twice Fruit Logistica) in Germany. In addition, we conducted a comprehensive review of the Lebensmittelzeitung - the leading German food and beverage newspaper - for the last five years. Discussing our hypotheses in the context of the German wine sector, in which cooperatives are still of high importance, we were able to show that power is a very useful tool for managing strictlycoordinated chains. However, depending on which source the power originates from, its effect may be completely different.
\end{abstract}

Key words: Power, Germany, Wine, Management

\section{Introduction}

The German retail sector has undergone a dramatic change over the last three decades. Whereas in the late 1980s retailers were still considered the secondary agents of food producers and their national brands, today retailers are not only dominating access to the consumers, but also setting the rules in the food market. A reason for this development is the increased concentration within this sector. At present, the ten largest retailers have over $90 \%$ of the market share, resulting in fierce competition. Hence, in order to differentiate, German retailers started to upgrade their own branded products so that retail brands and retail-branded products are now household names. Particular products (e.g., wine and champagne) and product categories (fruit and vegetables) were chosen in order to achieve this upgrading. However, due to some recent scandals (e.g., misnomer of expensive wines; high residuum of agro-chemicals in fruits and vegetables), retailers have to recognize that now, being a 'real' brand does not only mean receiving the profits of branding but also means being responsible for the overall product quality. It is observable that the perception of food quality in (German) society (consumers as well as politicians) has changed in recent years due to food scandals (BSE / FMD, rotten meat scandal, etc.). The latest food scandals concerning dioxin-contaminated feedstuffs and the outbreak of enter hemorrhagic Escherichia coli (EHEC) in Germany have illustrated its possible consequences which can be very serious not only for the health of consumers but also for the economy of the whole food chain. Therefore, now brand owners are not only liable for the quality of their own product but also for each step throughout the whole supply chain, including the quality of the ingredients. Hence, more and more vertically coordinated agri-food business (strictly coordinated chain organizations) is evolving.

Since the evolution of chain organizations is prompted by a dominating party (such as a supply-chain captain), and other network actors are more or less heavily dependent on this focal actor (Wildemann, 1997), such collaborations become very specific networks. These networks belong to the type of strategic networks characterized as 'pyramidal-hierarchic collaborations' (Jarillo, 1988). In the context of vertical coordination, such networks are also called "netchains" (Lazzarini et al., 2001) or "supply chain 
networks" (Hanf \& Kühl, 2004). These vertically coordinated chain networks have a strategic goal, e.g., producing better quality or lowering costs. Therefore, they have a centralized coordination of all efforts and processes - hence, a strategic (chain) management. Because the supply chain captain is the initiator, designer, and coordinator of the network, it is obliged to conduct the managerial tasks: to get the other network members to pursue the chain's goals, even if it is against their own interests. Because of the existing dependencies and power asymmetries, the chain captain is able to fulfil these tasks by coordinating the other network firms in a hierarchical style, i.e., the focal company has to have the power to align the actions of the network partners. However, at the same time the chain captain has to be careful not to inhibit the willingness of the other network participants to cooperate. Because of this paradox of cooperation and, simultaneously, (strict) coordination, the actual role that power plays in supply chains and networks has been discussed in varying ways. For many decades, there has been discussion about positive and negative effects of power (Craig and Gabler, 1963), so that all opinions about the importance and crucial role of power in the supply chain can be virtually split into two groups. The first group sees power as the major opponent of cooperation (Gaski 1984; Giebels et al. 1998; Lawler and Yoon 1996), with those in power being allowed to control others and to demand more value (Cox, 2001; Caldwell 2003; Watson et al., 2003) or maximize their own outcomes at the cost of others, leading to opportunism by partners (Yaqub, 2009).

This withdraws many of the relational elements that are necessary for the development of effective supply chain relationships. However, the second group sees that the concept of power is not necessarily negative (Dapiran and Hogarth-Scott, 2003; Hingley, 2005). It is considered a central concept because of its ability to condition others (Thorelli, 1986) and to stimulate necessary actions without the emotional attachment trust creates (Ireland et al., 2005). Therefore, this ability of power distinguishes it as an effective tool in coordinating and promoting harmonious relationships, solving conflicts, and enhancing the performance of the entire network and its members (Bierstedt, 1950; Blau, 1964; Bachmann, 2001; Chung and Kim, 2003; Corsten and Kumar, 2005; Sodano, 2006). The first aim of our article can be characterized by the problem setting. It is obvious that by speaking about power in supply chain networks, we do not refer to market power. However, what is power? Research shows that there is no unanimous answer to this question. Therefore, the first aim of our research is to elaborate on the question of power. Furthermore, we will construct some hypotheses regarding the use of power as a chain management instrument. After clarifying the concept of power and conceptualising its effect on strictly coordinated chain organisations in general, we will continue by applying our ideas to the German wine sector.

Hence, our second aim is to apply our general findings to the wine production chain, analysing the power play between cooperatives and retailers, and between cooperatives and their members. Due to the explorative nature of our study, we based the elaboration of our second aim on oral interviews, which were conducted in 2009, as well as in 2010, at five major international food and beverage fairs (twice ProWein, Anuga, and twice Fruit Logistica) in Germany. Furthermore, we strengthened this section with findings from a survey that was conducted for another project, but was found to have several results what was well suited for this study as well. In addition, we conducted a comprehensive review of the Lebensmittelzeitung - the leading German food and beverage newspaper - for the last five years. The structure of this article is as follows. At first, we present theoretical background on the concept of power and formulate hypotheses about the effects of power on coordination and cooperation in supply chain networks in general. In the next section, we elaborate on the study domain, which is the German wine sector. Afterwards, we discuss the power distribution and its implications for wine supply chain networks. The article concludes with a summary.

\section{Literature Review}

The concept of power: Several studies on marketing channels have shown that channel power has a significant impact on the buyer-supplier relationship and performance in channel distribution (Liu and Wang, 2000; Lee, 2001; Hingley, 2005; Leonidou et al., 2008; Zhao et al., 2008; Yeung et al., 2009; Sheu and $\mathrm{Hu}, 2009$ ). The power relationship also has implications in the development of partnerships, as does the structure of the power-dependence relationship (Kumar, 2005). It is agreed that power is central to understanding the nature of the supply network, the power structures that exist within it, and to implementing procurement and supply chain strategies (Cox, 2001, 2003; Crook and Combs, 2007; Ireland and Webb, 2007; Flynn et al., 2008; Ganesan et al., 2009; Sheu and Hu, 2009). Research has shown that the role of power is crucial in supply chains and networks since it can seriously impede cooperation 
through its interactions with other elements of the relationship (Cox, 2001; Caldwell 2003; Watson et al., 2003; Corsten and Kumar, 2005; Tokatli, 2007; Yaqub, 2009). Others, however, do not see power in supply chains as a solely negative force (Chung and Kim, 2003; Hingley, 2005; Maloni and Benton, 2000; Sodano, 2006). According to the literature, there is no doubt that power is a very important issue when studying supply chain networks and marketing channels, but what is power? It seems that there has been much disagreement about its exact definition. In fact, the problem with defining the concept of power is that it has many various definitions and conceptualizations (Dahl 1957). Authors who have focused on this problem agree that power is an extremely troublesome, elusive, notoriously evanescent and subjective concept (Bierstedt, 1950; Bachrach and Baratz, 1962; Ramsay, 1996); a vague, poorly defined 'primitive' term (Hage, 1972); and a difficult idea to pin down (Clegg et al., 2006). After reviewing roughly 250 definitions of power from the fields of sociology, psychology, political science, economics, management, marketing and chain and network science we fully agree with Cartwright (1959) who points out that many authors 'invent' their own definitions in order to suit their needs.

Following the advice of Bacharach and Lawler (1980), who state that 'when doing research in order to capture the term of power we must identify a more concrete phenomenon or idea to which the primitive term points', we concentrate on definitions presented in the field of supply-chain and marketing-channel literature. Most definitions of power within studies on marketing channels are based on the definition by El-Ansary and Stern (1972), who define power as 'the ability of a channel member to control the decision variables in the marketing strategy of another member in a given channel at a different level of distribution'(p. 47). Power in supply chains is defined as 'the ability of a firm to own and control critical assets in markets and supply chains that allow it to sustain its ability to appropriate and accumulate value for itself by constantly leveraging its customers, competitors and suppliers' (Cox et al. 2002). The concept of critical assets in supply chains is based on the idea that some resources are considered scarce or unique and that with the combination of high value, uniqueness and scarcity, particular supply chain resources become critical assets. Hu and Sheu (2005) view power in terms of a strategy-influencing source that is oriented from one channel member to another (p. 448). As a result, power is viewed as a effectively applied means to gain certain objectives by utilizing influence strategies, once the power over another firm was attained (Hu and Sheu, 2003; Payan and McFarland, 2005). Other recent literature on power in supply chains and marketing channels uses more or less similar definitions of power and simply rephrase aspects of using power to influence other firms to act in a desired manner for economic gains (Ireland and Webb, 2007) or to get them do things that they would not normally do (Reid and Bojani, 2009) and having a great deal of influence over the other members (Cant et al., 2009).

An examination of all of these definitions of power from different perspectives allows us to conclude that power generally refers to the ability, capacity or potential to get others to do something; to command, influence, determine or control the behaviors, intentions, decisions or actions of others in the pursuit of one's own goals or interests against their will; as well as to induce changes, to mobilize resources, to restructure situations, etc. All definitions of power seem to use similar terms and have a common theme. French and Raven (1959) identified five types of power, each based on its source or origin: coercive, reward, expert, legitimate, and referent power. Coercive power enables an individual to punish others. In the supply chain network context, it reflects the fear of a network member to be punished if it fails to comply with the requirements of the focal company. Reward power depends on the ability of the power holder to offer rewards to others. If a focal company has access to resources, which are valuable for other network actors, it can make these network actors perform in a desired way. Expert power is derived from the skills or special knowledge of a particular subject. With a supply chain network, the expert power of a focal company can be achieved if the network actors believe that it possesses a special knowledge, which is valuable to them. Legitimate power stems from a legitimate right to influence and an obligation to accept this influence. In this case, a focal actor is recognized in the eyes of the network members as having a right to make specific decisions. Referent power depends on an ability to be attractive to others and depends on the charisma and interpersonal skills of the power holder. In the supply chain context, this power is observed when network actors want to join a network.

Hypotheses in the context of supply chain networks: Substantive literature has found that coercive power led to an undesirable cooperative relationship (Brown et al., 1995; Maloni and Benton, 2000; Benton and Maloni, 2005). The use of coercive power may have a negative effect in the sense that the weaker parties may lose interest in the relationship. However, some authors see coercive power as having a positive effect in promoting coordination and development of stable relationships (Stern and E1Ansary, 1992; Bachmann, 2001). 


\section{H1: within a supply chain network, the perceived use of coercive power will positively affect coordination and negatively affect cooperation}

Effective coordination of exchange relationships has been observed as a positive effect of legitimate power, as the distribution of power becomes legitimate over time (Frazier and Antia, 1995; Kalafatis, 2000), and a more standardized business format is applied, such as contracts (Mohr et al., 1996; Lusch and Brown, 1996; Jap and Ganesan, 2000). However, the capacity to take legal action, especially to impose legal sanctions, could be perceived as a punishment (Gaski, 1986).

H2: within a supply chain network, the perceived use of legitimate power will positively affect coordination and negatively affect cooperation

Referent power was ranked highest amongst other power bases in connection to satisfaction (Lee and Low, 2008). As cooperation has been found to go hand in hand with satisfaction (Gaski, 1984; Dapiran and Hogarth-Scott, 2003), we suppose that the use of referent power will foster the development of cooperation. However, referent power might not be sufficient to motivate the power target to implement certain tasks, since it does not represent an explicit statement of the desired behaviour.

H3: within a supply chain network, the perceived use of referent power will negatively affect coordination and positively affect cooperation

Etgar (1976) states that an expert power source may be less effective as it is less flexible and is often viewed as unrelated to specific performance by channel members. Its effectiveness may also decline over time. However, expert power is perceived as positive when solicited and given. Offering free advice through an agency and advisory staff as part of project implementation is seen to be a valuable incentive for the power target to get involved in the project (Davies et al., 2004).

H4: within a supply chain network, the perceived use of expert power will negatively affect coordination and positively affect cooperation

Assuming that reward power is perceived as having an element of coercion, reward power will have a positive effect on coordination, since both reward and punishment provoke rapid changes in behavior (Dickinson, 2001). However, reward power also provides extrinsic motivation, which drives participants to comply with the requirements in order to achieve favorable outcomes (Zhao et al., 2008) and to create harmonious and enduring interorganizational exchange relationships (Gaski, 1986).

H5: within a supply chain network, the perceived use of reward power will positively affect coordination and cooperation.

\section{Study Domain}

The German wine sector and cooperatives: Whereas in the 1980s retailers were still dominating in direct sales and sales of specialised wine and delicacies, today the three main distribution channels are discount retail chains (40\% market share), retailers (36\% market share), and direct sales from the producers (20\% market share) (Schweickert, 2007). (See appendix 1 for a detailed presentation of the German wine sector). The increase of imported wines came hand in hand with the rise of supermarkets and discount chains- particularly from the New World. These large-scale producers are able to produce large quantities with an acceptable ('drinkable') quality at the lowest prices. Furthermore, these producers targeted retailers as their main distribution channel from the beginning, providing them with demanded quantities, modern IT and supply chain solutions. In contrast, the German wine sector is still dominated by small wine growers, with more than 30,000 wine businesses. Nearly half of these businesses cultivate less than 1 ha of vineyard while only about 2,000 wine growers own more than 10 ha. The majority of wine growers are members of cooperatives. (Schweickert, 2007) The rapid rise of supermarkets and discount chains was accompanied or caused by a change in consumer behaviour. Traditionally, in Germany, wine was mainly drunk in wine-growing regions. This wine was generally produced locally and bought directly from the growers or village cooperatives. However, today wine is drunk all over Germany (including non-wine growing regions) and most consumers are occasional wine drinkers.

Hence, they are looking for uncomplicated signals, such as the reputation of retailers or wine-growing regions or countries, as well as brands, to signify quality. Particularly imported wines with an easily understandable and asymmetric information-reducing label could profit from this development (Schweickert, 2001). Furthermore, retailers as customers are particularly interested in professional supply chain management, in terms of delivery time as well as minimum quantities. Therefore, only very 
large wine processors are able to meet these demands. For these reasons, only a few German private wineries and wine cooperatives are able to supply the large retailers on a national level. Wine cooperatives produce over 3 million hectolitres wine, accounting for nearly $35 \%$ of the total wine production in Germany. The acreage planted with vines by all members increased up to 31,342 ha, so that more than 31\% of all German land area was under cultivation, in particular, in the regions of Baden, Württemberg, and Franken, where grape production is dominated by part-time viticulturists and membership in cooperatives is widespread. In these regions, cooperatives hold a market share of nearly 75\%. Today, there were over 200 active wine cooperatives. However, only 147 of them possessed their own vinification facilities. (Schweickert, 2007) The examination of the German wine market has shown that wine cooperatives have a special role within the market. According to their statutes, wine cooperatives are self-help organizations for wine growers. Their aim is to improve the economic situation of their members by collaboration in vinification and marketing of the grapes or their processed products. Accordingly, the general function of wine cooperatives is to process grapes; produce must; and vinificate (fermentation, fining, clearing, and other oenological practices in the cellar for winemaking), bottle, and market the wine. Thus, the wine cooperatives are indispensable to part-time wine growers (Hoffmann, 2000).

In accordance with the general cooperative system, a secondary "central-wine cooperative" ("central cooperative") has been established in both of the wine-growing regions of Baden and Württemberg, where there are more than 68 non-vinificating wine cooperatives. For these cooperatives, "central cooperatives" function as the vinificating unit so that such cooperatives only have to collect the grapes of their wine growers and deliver the grapes of the whole vintage. Another task of the "central cooperative" is to stabilize the supply. Therefore, many of the wine cooperatives with their own vinification ("wet" wine cooperatives) deliver a contractual share of bulk wine from their vintage. Traditionally, wine cooperatives sold the vast majority of their wines directly to the consumers or sold them via small local retailers in their neighbourhood. However, due to the changes in consumer behaviour and in marketing channels, cooperatives must use different distribution channels to market their products (Hanf \& Kühl, 2008). Facing the demands of the large retailers, like continuously supplying them on a national basis, has led to some structural adjustments in the cooperative sector. Because the majority of the "wet" wine cooperatives do not create enough quantity and financial assets, they cannot afford to have their own distribution force. Thus, secondary "central wine cooperatives" have gained importance. They mainly operate higher within the wine production chain, selling bottled wine from "wet" wine cooperatives to retailers nationwide. Because they are centralized and market large quantities, they are able to meet the retailers' demands of high quantities paired with high demands of the IT infrastructure (Schweickert, 2007).

In general, the "central wine cooperatives" mediate between the primary cooperatives and the retailers by marketing wine nationwide and managing the relations with the retailers. Therefore, "wet" wine cooperatives can focus their marketing efforts on specialized retailers (special wine stores), local retailers, restaurants, and direct selling. Furthermore, traditionally co-operatives face quality problems that esteem from their governance structure. First, as there is the imperative of treating all members equal cooperatives have a problem to pay for different grape qualities different prices. Hence, as a result members had an incentive to sell their best grapes to other processors e.g. private wineries delivering to the co-operatives the not so good grapes. Second, as Eilers and Hanf (1999) have shown co-operatives face a so called double principal-agent problem. On the one hand, members as grape suppliers are acting as agents in the supply process but being the legal owner of the co-operatives they are at the same time the principals in the governance structure. Simultaneously the mangers of the co-operatives are in the supply process the principals whereas as employees they are the agents in the governance structure. This situation can lead to quality problems, as the management will be very careful to apply strict quality controls to the delivered grapes being delivered by the legal owners (Hanf \& Schweickert 2003). As this situation prevents selective terms of delivery or the usage of monitoring equipment such as the 'grape scan', an adverse selection process could be the result.

In addition, wine cooperatives face the same problems as other cooperatives, such as free-riding problems, horizon problems, portfolio problems, control problems, and influence cost problems (Cook, 1995). These issues have lead German retailers to build new collaborations with private wineries rather than with cooperatives. For example, in order to offer high-quality German red and white wine, the leading discount chain created an agreement with a leading winery in Baden. The winery agreed to deliver a certain quantity at a given (high) quality year-round. However, in order to be able to fulfil these 
requirements, they had to cooperate with a multitude of grape growers. In order to deliver their grapes, these growers (some are members of cooperatives) had to accept the strict quality measures and allow the winery oenologists to inspect and monitor the grapes year-round and to tell the growers which applications and cuts need to be made (LZ 2009a,b). This example shows that, in order to stay in the retail marketing channels that are strictly vertically coordinated, one has to accept their demands and be able to influence the decisions and the processes of their own suppliers. Hence, in this situation, power could be considered as key to a successful chain management.

\section{Discussion of main findings: Power distribution along the wine chain}

Having clarified the construct power and formulated hypotheses in the context of supply chain networks, we have to acknowledge that elaborating on the actual power distribution in a supply chain - e.g., in the wine chain - is a great challenge. Reducing this discussion to the market shares of certain players and then comparing these positions is by far not enough. In order to conquer this challenging task in the following paragraph, we will first consider power within the relationship between retailer and cooperative. Afterwards, we will address power between cooperatives and their members. In order to exemplify our hypothesis, we conducted twelve interviews with leading managers of Germany's wine industry. We approached managers of the top five retailers at three major food and beverages fairs in 2009 . Furthermore, at the same fairs, we also conducted further interviews with managers of specialised wine retailers, wine cooperatives, and consultants, which were specialised in supply-chain management in the wine business. These oral interviews were unstructured and lasted roughly 30 minutes. Ex ante, we reviewed newspaper articles from the Lebensmittelzeitung (the leading German newspaper of the food and beverage sector) from the last five years in order to be prepared for the in-depth interviews. In preparation for the interviews, we also used results from previous studies. Furthermore, one of the authors has had many years of professional experience as a winemaker and as a consultant in the wine business.

Retailers - cooperatives: Our newspaper review showed that retailers in Germany use the wine and champagne category in order to upgrade their retail brand (LZ 2007a, b). One retail manager stated that in his/her opinion, German wine cooperatives generally do not sell via well-known brands. Thus, he continued, they assume that if a consumer buys wine in a supermarket, the retailer is held liable for the product quality. An expert added that in the case of discount chains - accounting for $40 \%$ of total wine sales - wineries and wine cooperatives most likely do not want to be recognized so they will remain unknown to consumers. Thus, if the retailer's reputation/brand is held liable for the quality, it will demand control within the wine chain in building a supply-chain network. Another retail manager stated that, by being liable for quality, his supermarket chain has to command the ability to influence the decisions and actions of their suppliers for supermarkets' interest. Several cooperative managers spoke about the threat of blacklisting as the main source of coercion with retailers. Hence, we assume that particularly the network structure (pyramidal-hierarchical) gives the retailer coercive power. The retail managers agreed that they consider threats as a particularly effective means to achieve good coordination of the alignment of actions of their suppliers, e.g., on time delivery. However, at the same time, a cooperative manager told us that because of the frequent use of threats, he would stop the collaboration as soon as possible. One expert told us that in the case where a cooperative invests in special SAP software, retailers are willing to give better conditions. However, the use of reward power by retailers was found only - as in the example -- when cooperatives implemented certain IT-enablers, such as EDI, and retailers would honour these efforts by creating conditions that are more favourable.

Retail managers, as well as cooperative managers, said that in these instances both coordination and the willingness to cooperate increased. One interviewee said that retailers command strong market positions, which preclude arguments with them about their demands. This perception was shared by some other managers and experts. However, all said that the retailer's position of power does not motivate them to collaborate more closely, nor does it help with the coordination efforts. All agreed that since retailers interact intensively with consumers, retailers possess an enormous amount of knowledge about consumer demands and wishes and can therefore order their suppliers to produce exactly according to their specific standards. This shows that through expert power, retailers are very capable of influencing the actions of their suppliers. At the same time, none of the respondents indicated that these efforts negatively affected their willingness to cooperate. In a few cases, retailers with a good reputation (this statement was particularly emphasised by specialized wine retailers) could use referent power. In these cases, as the wine cooperatives hope to benefit from the retailers' fine reputation by becoming one of 
their suppliers were willing to accept the demands of the retailers more or less "cheerfully". Thus, we conclude that retailers use all power sources in order to regulate the market. As stated in our hypothesis, the use of the different power sources affects both the alignment of actions (coordination) and the alignment of interests (cooperation) differently. We found at this time, retailers mainly use coercive power, which is effective in chain coordination, but which deteriorates the collaboration between the retailers and their suppliers.

Secondary (central) cooperatives - primary cooperatives - members: The retail managers interviewed made it very clear that they demand large quantities and such quantities are only available from the secondary (and a few large primary) cooperatives. Therefore, we conclude that these cooperatives are gaining in position power. The retail managers confirmed that they make high demands on the IT-infrastructure of their suppliers and once again only the secondary (and a few large primary) cooperatives are regarded as being capable of acquiring the demanded technology and the special knowledge needed to work with it. Thus, due to the increasing demand of special knowledge, secondary cooperatives are able to build up expert power. Overall, it seems as if the secondary cooperatives and a few large primary cooperatives are gaining in power. However, both primary cooperative managers as well as some experts pointed out that due to the governing structure of secondary cooperatives, they command a higher degree of reward power and a lesser degree of coercive power because the management can easily implement a reward system but find it more difficult to implement a monitoring or sanction system addressing the processes connected with their owners - the primary cooperatives. Managers of primary cooperatives that deliver wine / grape juice to central cooperatives stated that when the central cooperatives try to use coercive power to achieve a better coordinated delivery, they refer to the demands of the retailers. The primary cooperatives accept these demands but do not like them affecting the relationship with the central cooperatives. In their opinion, the same results can be achieved by using reward systems. The retail and cooperative managers interviewed, as well as the experts, agree that the overall demands on quality have changed dramatically. Whereas previously wine quality relied solely on the vinification process itself, today the production methods of the grapes - i.e., the treatments in the vineyard during the whole year- are additional key elements for good wine quality. The cooperatives have to find possibilities to achieve a higher quality in the process of grape production. One is to use coercive means such as sanctions / price reductions when the grapes are delivered. A second alternative is to go to the wine growers and to offer on-farm assistance. In a previous study with interviews of 60 wet wine cooperatives, we found the following results (table 1).

Table 1: Applied means to enhance the overall wine quality

\begin{tabular}{llllll}
\hline & $\begin{array}{l}\text { Yield } \\
\text { Hectare }\end{array}$ & $\begin{array}{c}\text { per } \\
\text { Average } \\
\text { Oechsle }\end{array}$ & Grape Rating & $\begin{array}{l}\text { Assistance } \\
\text { programs }\end{array}$ & $\begin{array}{l}\text { Intensive } \\
\text { assistance } \\
\text { programs }\end{array}$ \\
\hline N Valid & 60 & 60 & 60 & 60 & 60 \\
Missing & 0 & 0 & 0 & 0 & 0 \\
Mean & 2.22 & 1.82 & 3.00 & 2.08 & 1.97 \\
Modus & 1 & 1 & 5 & 1 & 1 \\
Std.-Deviation & 1.606 & 1.408 & 1.657 & 1.565 & 1.507 \\
Range $^{\mathrm{a}}$ & 4 & 4 & 4 & 4 & 4 \\
Minimum & 1 & 1 & 1 & 1 & 1 \\
Maximum & 5 & 5 & 5 & 5 & 5 \\
\hline
\end{tabular}

Source: own performance

In our survey, $71.7 \%$ of the "wet" wine co-ops pay the viticulturist according to their "yield per hectare." Through this payment measure, they encourage the winegrowers not to exaggerate the potential of the vines, resulting in higher wine quality. Because the value of the "Average Oechsle" with 1.82 is, lower than the one for "yield per hectare," "wet" wine co-ops (80\%) apply the measure "Average Oechsle" more often. One reason is that this procedure has a self-financing character; the viticulturists are not paid until the vintage is over. Afterwards, they analyze the average degree Oechsle for every variety. Based on these results, they pay a surcharge to those viticulturists who delivered a higher level of above-average quality grapes (depending how much the grapes are above the average). Respectively, viticulturists who deliver below-average grapes are paid less. The payment depends on the sugar content. The least-used procedure of the system was rating the grapes before they are pressed. Forty-five percent of the "wet" wine co-ops did not use this procedure of negative-selection, in which grapes that do not match the minimum quality level are picked out. The cooperative managers interviewed agreed that one reason why the "wet" wine 
co-ops hesitate to implement this procedure is a lack of a positive incentive and the resulting negative effect if the grapes are not accepted after one year of hard work. $73.3 \%$ of the analyzed co-ops offer their viticulturists the option to rate the grapes during the year, but also offer basic assistance programs such as professional training and specialised seminars. Furthermore, bonuses (mark ups) are paid if the grapes match the set criteria. One further step is to offer intensive assistance programs, as implemented by 78.3 $\%$ of the "wet" wine co-ops.

The value 1.97 on the approval scale confirms that it serves an important role. Being an expert of wine production, the oenologist of the primary cooperative is in charge of the treatments within the vineyard and works with members in the vineyard to carry out the demanded cuts and application of fertiliser, pesticides, etc. These findings of our prior study were also confirmed by the recent interviews and show clearly that cooperatives have to be very cautious in using coercive power to achieve the alignment of actions. If they choose to use their expertise (expert power), they are capable of aligning the actions and at the same time increasing the willingness for member cooperation. One cooperative manager told us that he has the feeling that because the wine growers, as members, are also the owners of the primary cooperative, they identify themselves strongly with their cooperative. Because of this referent power, cooperatives are able to influence the decisions of their members. The importance of wine cooperatives as common institutions with a social impact, similar to a local government or a religious community, for their members is also confirmed by Hoffmann (2000). Overall, our respondents showed that cooperative management is able to exert non-coercive power (e.g., expert and reward power) more easily than coercive power in order to coordinate their suppliers (members). However, the respondents also agree that to a certain extent, the usage of coercive power is very useful and does not affect the cooperativeness of the members.

\section{Summary and Conclusion}

Currently, it can be observed that strictly vertically coordinated chains are gaining importance within the agri-food business sector. Such networks are managed by a 'supply chain captain,' i.e. - power is not distributed equally. Thus, power has to be considered as a main instrument for chain management. By clarifying the concept of power and identifying five different sources of power, we were able to build hypotheses of how power affects cooperation and coordination - the two main elements of chain management (Gulati et al. 2005). Discussing our hypotheses in the context of the German wine sector, in which cooperatives are still of high importance, we were able to show that power is a very useful tool for managing strictly coordinated chains. However, depending on which source the power originates from, its effect may be completely different. The 'stick or carrot' method (coercive or reward power) might have superb effects on coordination, since it provides extrinsic motivation to comply with the requirements in order to achieve favorable outcomes, but its overuse might hamper cooperation. On the other hand, noncoercive power types (legitimate, expert power, informational and referent power) might be more appropriate to facilitate cooperation but less effective for coordination, since they are less likely to be used in targeting a specific behaviour or performance, although they could provide intrinsic motivation and alignment of interests.

\section{References}

Bachmann, R. (2001). Trust, Power and Control in Trans-Organizational Relations. Organization Studies, 22(2), 337-365.

Bacharach, P. \& Baratz, M. (1962). The two faces of power. American Political Science Review, 56, 947-952.

Bacharach, S. B., \& Lawler, E. J. (1980). Power and politics in organizations. San Francisco: Jossey-Bass.

Benton, W. C. \& Maloni, M. (2005). The influence of power driven buyer/seller relationships on supply chain satisfaction. Journal of Operations Management, 23(1), 1-22.

Bierstedt, R. (1950). An analysis of social power. American Sociological Review, 15, 730-738.

Blau, P. (1964). Exchange and Power in Social Life. New York: John Wiley, 117.

Brown, J. R., Lusch, R. F. \& Nicholson, C. Y. (1995). Power and Relationship Commitment: Their Impact on Marketing Channel Member Performance. Journal of Retailing, 71(4), 363-392.

Caldwell, N. (2003). The Treatment of Power in Supply Chains: Power, Method and Ontology, 12th International IPSERA Conference, Budapest, 501-512.

Cant, M., Strydom, C. J. W., Jooste, C. J. \& du-Plessis, P. J. (2009). Marketing Management. Edition 5, Juta and Company Limited. 
Cartwright, D. (1965). Influence, leadership and control, In: J. G. March (Ed.), Handbook of organizations. Chicago: Rand McNally, 1-47.

Chung, S. A. \& Kim, G. M. (2003). Performance effects of partnership between manufacturers and suppliers for new product development: the supplier's standpoint. Research Policy, 32(4), 587603.

Clegg, S., Courpasson, D. \& Phillips, N. (2006). Power and organizations, SAGE Publication series.

Cook, M. L. (1995). The Future of U.S. Agricultural Cooperatives: A Neo-Institutional Approach. American Journal of Agricultural Economics, 77, 1153-1159.

Corsten, D. \& Kumar, N. (2005). Do suppliers benefit from collaborative relationships with large retailers? An empirical investigation of Efficient Consumer Response adoption. Journal of Marketing, 69(3), 80-94.

Cox, A. (2001). Understanding Buyer and Supplier Power: A Framework for Procurement and Supply Competence. Journal of Supply Chain Management, 37, 8.

Cox, A., Ireland, P., Lonsdale, C. H., Sanderson, J. \& Watson, G. (2002). Supply Chains, Markets and Power. Mapping buyer and supplier power regimes. Routledge studies in Business Organization and Networks.

Cox A. (2003). Supply Chains, Markets and Power: Mapping Buyer and Supplier Power Regimes, NetLibrary, Inc, Routledge.

Craig, D. R. \& Gabler, W. K. (1963). The competitive struggle for market control, In: Readings in Marketing (Westing, J.E., Ed.). Englewood Cliffs, New Jersey: Prentice Hall.

Crook, T. R. \& Combs, J. G. (2007). Sources and consequences of bargaining power in supply chains. Journal of Operations Management, 25(2), 546-555.

Dahl, R. (1957). The concept of power. Behavioral Science, 2, 201-215.

Dapiran, G. P. \& Hogarth-Scott, S. (2003). Are co-operation and trust being confused with power? An analysis of food retailing in Australia and the UK. International Journal of Retail \& Distribution Management, 31(5), 256-267.

Davies, B., Black stock, K., Brown, K. \& Shannon, P. (2004). Challenges in creating local agri-environmental cooperation action amongst farmers and other stakeholders, FINAL REPORT of Scottish Executive Environment and Rural Affairs Department, Aberdeen, UK.

Dickinson, D. (2001). The carrot vs. the stick in work team motivation. Experimental Economics, 4, $107-$ 124.

Eilers, C. \& Hanf, C. H. (1999). Contracts between Farmers and Farmers - Processing Co-operatives: A Principal-Agent Approach for the Potato Starch Industry, In: Galizzi, G. and L. Venturini (eds.) Vertical Relationships and Coordination in the Food System, Heidelberg, 267-284.

El-Ansary, A. L. \& Stern, L. W. (1972). Power measurement in the distribution channel. Journal of Marketing Research, 9, 47-52.

Etgar, M. (1976). Channel Domination and Countervailing Power in Distribution Channels. Journal of Marketing Research, 13, 254-262.

Flynn, B. B., Zhao, X., Huo, B. \& Yeung, J. H. Y. (2008). We have the power! How customer power affects supply chain relationships. Business Horizons, 51, 169-174

Frazier, G. L. \& Antia, K. D. (1995). Exchange relationships and interfirm power in channels of distribution. Journal of the Academy of Marketing Science, 23, 321-326.

French, J. R. P. \& Raven, B. (1959). The bases of social power, in: Cartwright, D. (Eds), Studies in Social Power, University of Michigan Press, Ann Arbor, MI, 150-167.

Ganesan, Sh., George, M., Jap, S., Palmatier, R.W., Weitz, B. (2009). Supply Chain Management and Retailer Performance: Emerging Trends, Issues, and Implications for Research and Practice. Journal of Retailing, 85 (1, 2009), pp. 84-94

Gaski, J. (1984). The Theory of Power and Conflict in Channels of Distribution. Journal of Marketing, Vol. 48, No. 3, (summer, 1984), pp. 9-29.

Gaski, J.F. (1986). The theory of power and conflict in channels of distribution. Journal of Marketing, Vol. 48 (3), pp. 9-29.

Giebels, E., De Dreu C.K.W. \& van de Vliert, E. (1998). The alternative negotiator as the invisible third at the table: The impact of potency information. International Journal of Conflict Management, 9, pp. 5-21.

Gulati, R. \& Sytch, M. (2005). Exploring the effects of organizational interdependence on performance: the role of embeddedness and power, working paper, Kellogg School of Management, North-western University.

Hage, J. (1972). Techniques and Problems of Theory Construction in Sociology, Wiley, New York. 
Hanf, J. \& Kühl, R. (2008). Genossenschaften im Wandel der deutschen Agrar- und Ernährungswirtschaft. Berichte über Landwirtschaft, 86(1), 162-178.

Hanf, J. \& Kühl, R. (2004). Strategy focussed Supply Chain Networks, In: Bremmers, H.J., Omta, S.W.F., Trienekens, J.H and E.F.M. Wubben (eds.). Dynamics in Chain and Networks. Wageningen Academic Publishers, 104-110.

Hanf, J. H. \& Schweickert, E. (2007). How to deal with member heterogeneity - management implications. International Journal of Cooperative Management, 3, 40-48.

Hingley, M. (2005). Power to all our friends? Learning to live with imbalance in UK supplier-retailer relationships. Industrial Marketing Management, 34(8), 848-858.

Hoffmann, D. (2000). Winzer Genossenschaften - Mehr Marktorientierung gefordert. Weinwirtschaft, 3, 20-26.

Hu, T. L. \& Sheu, J. B. (2005). Relationships of Channel Power, Noncoercive Influencing Strategies, Climate, and Solidarity: A Real Case Study of the Taiwanese PDA Industry. Industrial Marketing Management, 34(5), 447-461.

Hu, T. L. \& Jiuh-Biing, S. (2003). A Fuzzy-based Customer Classification Method for Advanced DemandResponsive Logistical Distribution Operations. Fuzzy Sets and Systems, 139, 431-450.

Ireland, R. D. \& Webb, J. W. (2007). A multi-theoretic perspective on trust and power in strategic supply chains. Industrial Marketing Management, 3, 482-497.

Ireland, R. D., Hitt, M. A. \& Webb, J. W. (2005). Entrepreneurial alliances and networks, In: Shenkar, O., Reuer, J.J. (Eds.), Handbook of Strategic Alliances. Sage Publications, Thousand Oaks, CA, 333-352.

Jap, S. D. \& Ganesan, S. (2000). Control Mechanisms and the Relationship Life Cycle: Implications for Safeguarding Specific Investments and Developing Commitment. Journal of Marketing Research, 37(2), 227-245.

Jarillo, J. C. (1988). On strategic networks. Strategic Management Journal, 9, 31-41.

Kalafatis, S. P. (2000). Buyer - seller relationships along channels of distribution. Industrial Marketing Management, 31, 215-228.

Kumar, N. (2005). The power of power in supplier-retailer relationships. Industrial Marketing Management, 34, 863-866.

Lawler, E. J. \& Yoon, J. (1996). Commitment in Exchange Relations: Test of a Theory of Relational Cohesion. American Sociological Review, 61, 89-108.

Lazzarini, S. G., Chaddad, F. R. \& Cook, M. L. (2001). Integrating supply chain and network analyses: The study of netchains. Journal on Chain and Network Science, 1, 7-22.

Lee, K. L. \& Low, G. T. (2008). The Exercise of Social Power and the Effect of Ethnicity: Evidence from Malaysian's Industrial Companies. International Business Research, 1(2), 53-65.

Lee, D. Y. (2001). Power, Conflict, and Satisfaction in IJV Supplier-Chinese Distributor Channels. Journal of Business Research, 52, 149-60.

Leonidou, L. C., Talias, M. A. \& Leonidou, C. N. (2008). Exercised power as a driver of trust and commitment in cross-border industrial buyer-seller relationships. Industrial Marketing Management, 37, 92-103.

Liu, H. \& Wang, Y. P. (2000). Interfirm Channel Relationships, Influence Strategies and Performance in China: An Empirical Examination, In: Culture and International Business, Kip Becker, Ed.: The Haworth Press, Inc.

Lusch, R. F. \& Brown, J. R. (1996). Interdependency, Contracting, and Relational Behavior in Marketing Channels. Journal of Marketing, 60, 19-38.

LZ. (2009a). Fritz Keller bringt Rose. Lebensmittelzeitung, 09.04.2009:19.

LZ. (2009b). Discounter punkten beim Wein. Lebensmittelzeitung, 07.08.2009:20.

LZ. (2007a). Marken brauchen Zeit. Lebensmittelzeitung, 23.03.2007:38.

LZ. (2007b). Aldi investiert in Wein. Lebensmittelzeitung, 23.03.2007:1.

Maloni, M. J. \& Benton, W. C. (2000). Power Influences in the Supply Chain. Journal of Business Logistics, 21(1), 49-73.

Mohr, J. J., Fisher, R. J. \& Nevin, J. R. (1996). Collaborative Communication in Interfirm Relationships: Moderating Effects of Integration and Control. Journal of Marketing, 60(3), 103-115.

Payan, J. M. \& McFarland, R. G. (2005). Decomposing Influence Strategies: Argument Structure and Dependence as Determinants of the Effectiveness of Influence Strategies in Gaining Channel Member Compliance. Journal of Marketing, 69, 66-79.

Ramsay, J. (1996). Power Measurement. European Journal of Purchasing \& Supply Management, 2(12), 129-143.

Reid, R. D. \& Bojanic, D. C. (2009). Hospitality Marketing Management, Edition 5, John Wiley and Sons.

Schweickert, E. (2001). Classic und Selection. Der Oenologe, 29, 3-4. 
Schweickert, E. (2007). Unternehmensstrategien in der Weinwirtschaft im Rahmen der EUWeinmarktordnungspolitik. Dissertation, DLG-Verlag, Frankfurt, Germany.

Sheu, J. B. \& Hu, T. L. (2009). Channel power, commitment and performance toward sustainable channel relationship. Industrial Marketing Management, 38(1), 17-31.

Sodano, V. (2006). A Power-based Approach to the Analysis of the Food System, In: International agri-food chains and networks. J. Bijman, S.W.F. Omta, J.H. Trienekens (Eds.). Wageningen, Wageningen Academic Publishers, 199-215.

Stern, L. W. \& EI-Ansary, A. I. (1992). Marketing channels, Englewood Cliffs, NJ: Prentice-Hall (4th Ed.)

Thorelli, H. B. (1986). Networks: between markets and hierarchies. Strategic Management Journal, 7, 37 51.

Tokatli, N. (2007). Asymmetrical power relations and upgrading among suppliers of global clothing brands: Hugo Boss in Turkey. Journal of Economic Geography, 7, 67-92.

Watson, G., Lonsdale, C., Cox, A. \& Chicksand, D. (2003). Effective Demand Management in the NHS, 12th International IPSERA Conference, Budapest, 1113-1125.

Wildemann, H. (1997). Koordination von Unternehmensnetzwerken. Zeitschrift für Betriebswirtschaft, 67(4), 417-439.

Yaqub, M. Z. (2009). Antecedents, Consequences and Control of Opportunistic Behavior in Strategic Networks. Journal of Business \& Economics Research, 7(2), 15.

Yeung, J. H. Y., Selen, W., Zhang, M. \& Huo, B. (2009). The effects of trust and coercive power on supplier integration. International Journal of Production Economics, Special Issue on Operations Strategy and Supply Chains Management, 120(1), 66-78.

Zhao, X., Huo, B., Flynn, B. B. \& Yeung, J. H. Y. (2008). The impact of power and relationship commitment on the integration between manufacturers and customers in a supply chain. Journal of Operations Management, 26, 368-388. 
Appendix 1: The German Wine Market and the Role of the Cooperatives

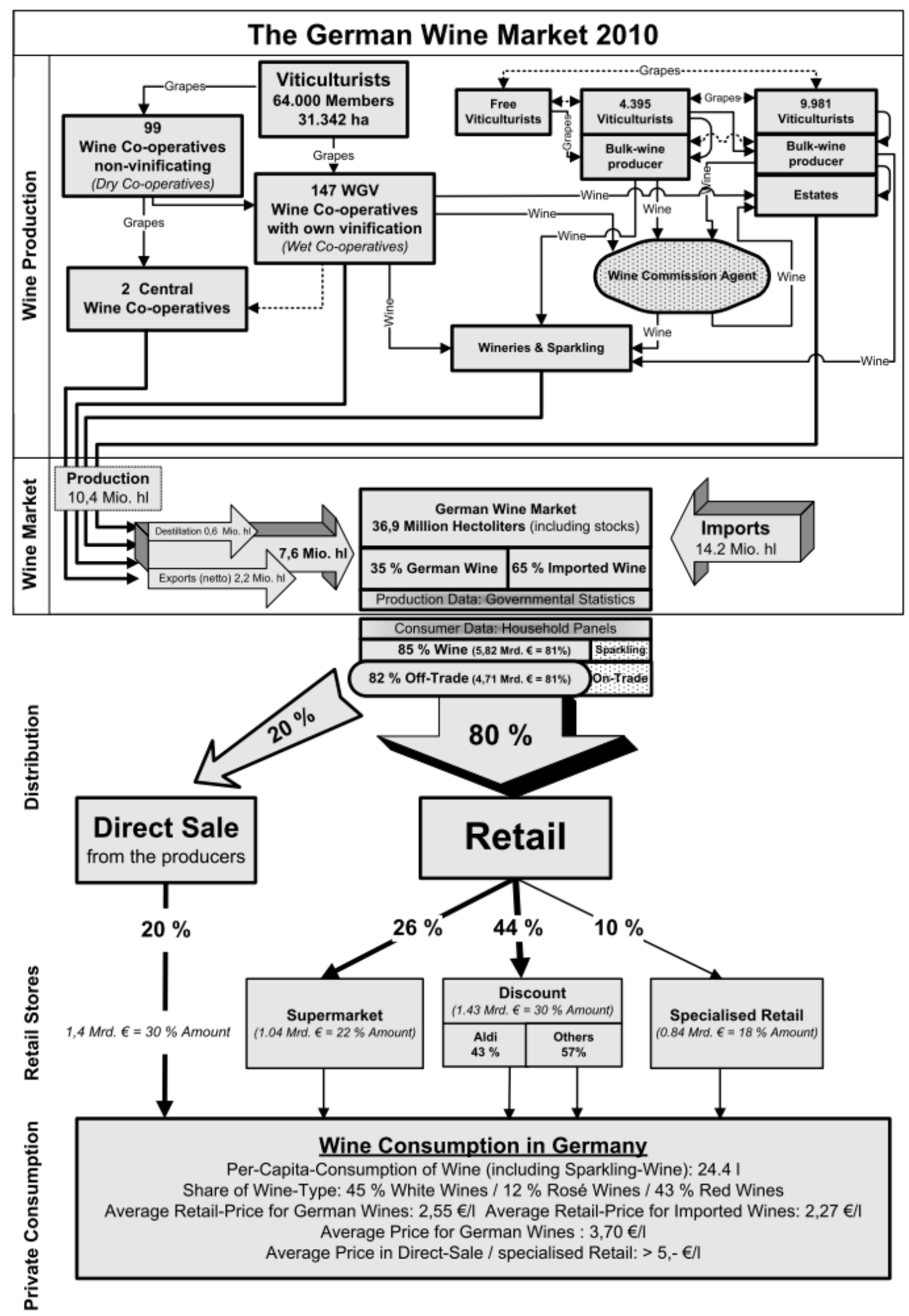

